\title{
ANALISIS KINERJA KEUANGAN PEMERINTAH DAERAH KOTA BANDAR LAMPUNG SEBELUM DAN SETELAH MEMPEROLEH OPINI WTP
}

\author{
Rosmiaty Tarmizi \\ Khairudin \\ Ayu Jayadi \\ (Universitas Bandar Lampung) \\ Email: rosmiati@ubl.ac.id \\ Email: udinkumis@yahoo.com
}

\begin{abstract}
This research aims to determine the local government's financial performance Bandar Lampung city before and after obtaining WTP. Method opinion research using qualitative methods and quantitative methods of descriptive analysis with Paired Sample t Test different quantitative Test. Data used in this study is a local government financial reports (LKPD) 2008- 2012 Bandar Lampung city that has been audited by BPK-RI region Bandar Lampung.

Conclusion result this study found that the financial performance of the city government after the Bandar Lampung city WTP's opinion is different with before WTP's opinion, which means the local government's financial performance Bandar Lampung city after WTP's opinion is better before WTP's opinion.
\end{abstract}

Keywords: Financial Performance, Local Government, WTP Opinion

\section{Latar Belakang Masalah}

Sejak Pemerintah Daerah Kota Bandar Lampung memperoleh opini WTP murni dalam 3 tahun berturut-turut yaitu 2010, 2011, dan 2012 berdasarkan hasil pemeriksaan Badan Pemeriksa Keuangan Perwakilan Provinsi Lampung hal ini menunjukkan bahwa pengelolaan keuangan Pemerintah Kota Bandar Lampung sudah relatif baik. Namun opini WTP yang diperoleh Pemerintah Daerah banyak menuai kasus. Jangan sampai masyarakat menganggap status WTP lembaga negara pusat dan daerah sebagai jaminan bersih dari penyimpangan dan korupsi.

Hasil analisis rasio keuangan ini digunakan untuk tolak ukur untuk menilai kemandirian keuangan daerah dalam membiayai penyelenggaraan otonomi daerah, mengukur efektifitas dalam merealisasikan pendapatan asli daerah, mengukur efisiensi dalam melakukan pengeluaran yang dibelanjakan sesuai dengan peruntukkannya dan memenuhi dari apa yang direncanakan, mengukur sejauh mana aktifitas pemerintah dalam membelanjakan pendapatan daerahnya untuk belanja modal, dan mengetahui seberapa besar kontribusi penerimaan komponen dalam pendapatan asli daerah dari pajak daerah dan retribusi daerah. 


\section{Landasan Teoritis dan Hipotesis}

\subsection{APBD}

\section{Definisi APBD}

Mardiasmo (2005:61), “Anggaran Pendapatan dan Belanja Daerah merupakan instrumen kebijakan yang utama bagi pemerintah daerah. Sebagai instrumen kebijakan, anggaran daerah menduduki posisi sentral dalam upaya pengembangan kapabilitas dan efektivitas. Anggaran daerah digunakan sebagai alat untuk menentukan besar pendapatan dan pengeluaran, membantu pengambilan keputusan dan perencanaan pembangunan.

\section{Fungsi APBD}

Berdasarkan Undang-Undang No. 33 Tahun 2004 Tentang Perimbangan Keuangan Pusat dan Daerah pasal 66 ayat 3, Anggaran Pendapatan Belanja Daerah (APBD) memiliki fungsi sebagai berikut:

1. Fungsi Otorisasi yang mengandung arti bahwa anggaran daerah menjadi dasar untuk melaksanakan pendapatan dan belanja pada tahun yang bersangkutan.

2. Fungsi Perencanaan yang mengandung arti bahwa anggaran daerah menjadi pedoman bagi menajemen dalam merencanakan kegiatan pada tahun yang bersangkutan.

3. Fungsi Pengawasan yang mengandung arti bahwa anggaran daerah menjadi pedoman untuk menilai apakah kegiatan penyelanggaraan pemerintahan sesuai dengan ketentuan yang telah ditetapkan

4. Fungsi Alokasi yang mengandung arti bahwa angaran daerah untuk mengurangi pengangguran dan pemborosan sumber daya, serta meningkatkan efisiensi dan efektifitas perekonomian.

5. Fungsi Distribusi yang mengandung arti bahwa kebijakan anggaran daerah harus memperhatikan rasa keadilan dan kepatuhan.

\section{Komponen dalam Anggaran Pendapatan Belanja Daerah (APBD)}

1. Pendapatan Pemerintah Daerah sebagaimana dimaksud dalam Undang-Undang No. 33 Tahun 2004 pasal 22 ayat (1) huruf a meliputi semua penerimaan uang melalui rekening kas umum daerah, yang menambah ekuitas dana, merupakan hak daerah dalam satu tahun anggaran dan tidak perlu dibayar kembali oleh daerah.

2. Belanja Daerah Halim (2001:19) mengartikan Keuangan daerah sebagai semua hak dan kewajiban yang dapat dinilai dengan uang, demikian pula segala sesuatu baik berupa 
uang maupun barang yang dapat dijadikan kekayaan daerah sepanjang itu belum dimiliki atau dikuasai oleh Negara atau daerah yang lebih tinggi serta pihak-pihak lain sesuai ketentuan atau peraturan undang-undang yang berlaku.

3. Pembiayaan digunakan untuk menutupi anggaran yang defisit yang bersumber dari dalam negeri maupun luar negeri.

\subsection{Keuangan Daerah}

\section{Definisi Keuangan Daerah}

Halim (2001:19) mengartikan Keuangan daerah sebagai semua hak dan kewajiban yang dapat dinilai dengan uang, demikian pula segala sesuatu baik berupa uang maupun barang yang dapat dijadikan kekayaan daerah sepanjang itu belum dimiliki atau dikuasai oleh Negara atau daerah yang lebih tinggi serta pihak-pihak lain sesuai ketentuan atau peraturan undangundang yang berlaku.

\section{Tujuan Keuangan Daerah}

Tujuan keuangan daerah menurut Devas, et.al, (1989) sebagai berikut:

1. Akuntabilitas (Accountability).

Pemda harus mempertanggungjawabkan tugas keuangan kepada lembaga atau orang yang berkepentingan dan sah. Lembaga atau orang yang dimaksud antara lain, adalah Pemerintah Pusat, DPRD, Kepala Daerah, masyarakat dan kelompok kepentingan lainnya (LSM);

2. Memenuhi Kewajiban Keuangan.

Keuangan daerah harus ditata sedemikian rupa sehingga mampu melunasi semua ikatan keuangan, baik jangka pendek maupun jangka panjang;

3. Kejujuran.

Urusan keuangan harus diserahkan pada pegawai profesional dan jujur, sehingga mengurangi kesempatan untuk berbuat curang.

4. Hasil guna (effectiveness) dan daya guna (efficiency) kegiatan daerah

Tata cara pengurusan keuangan daerah harus sedemikian rupa sehingga memungkinkan setiap program direncanakan dan dilaksanakan untuk mencapai tujuan dengan biaya serendah-rendahnya dengan hasil yang maksimal. 
5. Pengendalian.

Manajer keuangan daerah, DPRD dan aparat fungsional pemeriksaan harus melakukan pengendalian agar semua tujuan dapat tercapai. Harus selalu memantau melalui akses informasi mengenai pertanggungjawaban keuangan.

\section{Dasar Hukum Keuangan Daerah}

Untuk memperjelas pengelolahan dan pertanggungjawaban keuangan daerah, pemerintah membuat undang-undang sebagai dasar hukum keuangan daerah diantaranya:

1. UU No.32 Tahun 2004 Tentang Pemerintahan Daerah

2. UU No.33 Tahun 2004 Tentang Perimbangan Keuangan Pusat dan Daerah

3. UU No.17 Tahun 2003 Tentang Keuangan Negara

4. UU No.15 Tahun 2004 tentang Pemeriksaan Pengelolaan dan Tanggung Jawab Keuangan Negara

5. UU No.1 Tahun 2004 Tentang Perbendaharaan Negara

6. PP No.58 Tahun 2005 Tentang Pengelolaan Keuangan Daerah

7. PP No.71 Tahun 2010 Tentang Standar Akuntansi Pemerintahan

8. Permendagri No.21 Tahun 2011 Tentang Pedoman Pengelolaan Keuangan Daerah.

\section{3 Kinerja Keuangan Pemerintah Daerah}

\section{Definisi Kinerja Keuangan Pemerintah Daerah}

Kinerja keuangan pemerintah daerah adalah kemampuan suatu daerah untuk menggali dan mengelola sumber-sumber keuangan asli daerah dalam memenuhi kebutuhannya guna mendukung berjalannya sistem pemerintahan, pelayanan kepada masyarakat dan pembangunan daerahnya dengan tidak tergantung sepenuhnya kepada pemerintah pusat dan mempunyai keleluasaan didalam menggunakan dana-dana untuk kepentingan masyarakat daerah dalam batas-batas yang ditentukan peraturan perundang-undangan (Syamsi,1986: 199).

\section{Tujuan Pengukuran Kinerja Keuangan Pemerintah Daerah}

Menurut Mardiasmo, 2002: 121Pengukuran kinerja keuangan pemerintah daerah dilakukan untuk memenuhi 3 tujuan yaitu: Memperbaiki kinerja pemerintah, Membantu mengalokasikan sumber daya dan pembuatan keputusan, Mewujudkan pertanggungjawaban publik dan memperbaiki komunikasi dan kelembagaan. 


\section{Rasio Keuangan Sebagai Alat Pengukuran Kinerja Keuangan Pemda}

Beberapa rasio keuangan yang dapat digunakan untuk mengukur akuntabilitas pemerintah daerah (Halim, 2004: 233) yaitu rasio kemandirian, rasio efektifitas terhadap pendapatan asli daerah, rasio efisiensi belanja daerah, rasio pertumbuhan keuangan, dan rasio akitivitas keuangan daerah.

\section{Pihak-Pihak Yang Perlu Terhadap Rasio Keuangan}

Adapun pihak-pihak yang berkepentingan dengan rasio keuangan pemerintah daerah (Halim, 2004: 232) adalah :

1. DPRD sebagai wakil dari pemilik daerah (masyarakat).

2. Pihak Eksekutif sebagai landasan dalam menyusun APBD berikutnya.

3. Pemerintah pusat/provinsi sebagai masukan dalam membina pelaksanaan pengelolaan keuangan daerah.

4. Masyarakat dan kreditur, sebagai pihak yang akan turut memiliki saham pemerintah daerah, bersedia memberi pinjaman maupun membeli obligasi.

\section{4 Laporan Keuangan Pemerintah Daerah}

\section{Definisi Laporan Keuangan Pemerintah Daerah}

Menurut Peraturan Pemerintah (PP) Nomor 71 Tahun 2010 tentang Standar Akuntansi Pemerintahan (SAP) mendefinisikan laporan keuangan adalah suatu penyajian data keuangan termasuk catatan yang menyertainya (bila ada), yang dimaksudkan untuk mengkomunikasikan sumber daya ekonomi (aktiva) dan/atau kewajiban suatu entitas pemerintah pada saat tertentu atau perubahan atas aktiva dan/atau kewajiban selama suatu periode tertentu sesuai dengan standar akuntansi pemerintah.

\section{Tujuan Penyajian Laporan Keuangan Pemerintah Daerah}

Secara garis besar, tujuan umum penyajian laporan keuangan oleh pemerintah daerah menurut Mardiasmo (2002) adalah :

1. Untuk memberikan informasi yang digunakan dalam pembuatan keputusan ekonomi, sosial, dan politik serta sebagai bukti pertanggungjawaban dan pengelolaan.

2. Untuk memberikan informasi yang digunakan untuk mengevaluasi kinerja manajerial dan organisasional. 


\section{Komponen Laporan Keuangan Pemerintah Daerah}

Menurut Peraturan Pemerintah (PP) No.71 Tahun 2010 tentang Standar Akuntansi Pemerintahan Lampiran II, komponen laporan keuangan yang harus disajikan oleh pemerintah terdiri atas:

1. Laporan Realisasi Anggaran (LRA).

2. Neraca

3. Laporan Arus Kas

4. Catatan Atas Laporan Keuangan

\subsection{Audit Sektor Publik}

\section{Definisi Audit Sektor Publik}

Menurut Peraturan BPK-RI No. 1 Tahun 2007 Tentang Standar Pemeriksaan Keuangan Negara (SPKN), yang dimaksudkan pemeriksaan (auditing) adalah proses identifikasi masalah, analisis, dan evaluasi yang dilakukan secara independen, objektif, dan profesional berdasarkan standar pemeriksaan, untuk menilai kebenaran, kecermatan, kredibilitas, dan keandalan informasi mengenai pengelolaan dan tanggung jawab keuangan negara.

\section{Jenis-Jenis Audit Sektor Publik}

Adapun jenis-jenis audit sektor publik menurut Peraturan BPK-RI No. 1 Tahun 2007 Tentang Standar Pemeriksaan Keuangan Negara (SPKN) terdiri dari:

1. Audit Keuangan (Financial Audit)

Pemeriksaan keuangan adalah pemeriksaan atas laporan keuangan. Pemeriksaan keuangan tersebut bertujuan untuk memberikan keyakinan yang memadai (reasonable assurance) apakah laporan keuangan telah disajikan secara wajar, dalam semua hal yang material sesuai dengan prinsip akuntansi yang berlaku umum di Indonesia atau basis akuntansi komprehensif selain prinsip akuntansi yang berlaku umum di Indonesia.

2. Audit Kinerja (Performance Audit)

Pemeriksaan kinerja adalah pemeriksaan atas pengelolaan keuangan negara yang terdiri atas pemeriksaan aspek ekonomi dan efisiensi serta pemeriksaan aspek efektivitas. Dalam melakukan pemeriksaan kinerja, pemeriksa juga menguji kepatuhan terhadap ketentuan peraturan perundang undangan serta pengendalian intern. 
3. Audit Dengan Tujuan Tertentu

Pemeriksaan Dengan Tujuan Tertentu bertujuan untuk memberikan simpulan atas suatu hal yang diperiksa. Pemeriksaan Dengan Tujuan Tertentu dapat bersifat: eksaminasi (examination), reviu (review), atau prosedur yang disepakati (agreed-upon procedures). Pemeriksaan dengan tujuan tertentu meliputi antara lain pemeriksaan atas hal-hal lain di bidang keuangan, pemeriksaan investigatif, dan pemeriksaan atas sistem pengendalian intern.

\subsection{Opini Audit}

Berdasarkan Undang-Undang Nomor 15 Tahun 2004 tentang Pemeriksaan Pengelolaan dan Tanggung Jawab Keuangan Negara disebutkan bahwa terdapat empat (4) jenis opini audit yang diberikan oleh Badan Pemeriksa Keuangan (BPK) atas hasil pemeriksaan Laporan Keuangan Pemerintah (LKP). Masing-masing opini tersebut sebagai berikut:

1. Opini Wajar Tanpa Pengecualian (Unqualified Opinion)

Mahmudi (2006) menjelaskan bahwa "opini yang paling baik adalah wajar tanpa pengecualian (unqualified opinion)". Opini wajar tanpa pengecualian diberikan karena auditor meyakini bahwa laporan keuangan telah bebas dari kesalahan-kesalahan atau kekeliruan yang material.

2. Opini Wajar Dengan Pengecualian (Qualified Opinion)

Opini wajar dengan pengecualian menunjukan bahwa sebagian besar pos dalam laporan keuangan, posisi keuangan, hasil usaha, dan arus kas entitas tersebut telah disajikan secara wajar terbebas dari salah saji mateerial dan sesuai dengan prinsip akuntansi yang berlaku umum di Indonesia, kecuali untuk dampak hal-hal yang berhubungan dengan yang dikecualikan atau untuk pos-pos tertentu disajikan secara tidak wajar.

3. Opini Tidak Wajar (Adversed Opinion)

Opini tidak wajar adalah opini yang menyatakan bahwa laporan keuangan entitas yang diperiksa tidak menyajikan secara wajar posisi keuangan, hasil usaha, dan arus kas entitas tertentu sesuai dengan prinsip akuntansi yang berlaku umum di Indonesia. Keadaan seperti ini bisa terjadi karena buruknya sistem pengendalian internal dan sistem akuntansi yang ada (Mahmudi, 2007).

4. Pernyataan Menolak Memberikan Opini (Disclaimer Opinion)

Pernyataan menolak memberikan opini adalah opini yang menyatakan bahwa auditor tidak menyatakan pendapat atas laporan keuangan. Mahmudi (2007) menjelaskan 
bahwa auditor tidak dapat menyatakan pendapat atas hasil audit laporan keuangan karena dua alasan, yaitu auditor tergangganggu independensinya dan auditor dibatasi untuk mengakses data tertentu.

\subsection{Penelitian Terdahulu}

Berikut ini merupakan ringkasan hasil penelitian dari berbagai penelitian yang relevan mengenai analisis kinerja keuangan pemerintah daerah, sebagai berikut:

\section{Table 1}

\section{Ringkasan Hasil Penelitian Terdahulu}

\begin{tabular}{|c|c|c|c|}
\hline No & Peneliti & Judul Penelitian & Hasil \\
\hline 1 & $\begin{array}{l}\text { Erawati, } \\
2009\end{array}$ & $\begin{array}{l}\text { Analisis Kinerja } \\
\text { Keuangan Kawasan } \\
\text { SARBAGITA } \\
\text { (Denpasar, Badung, } \\
\text { Gianyar dan Tabanan) } \\
\text { Tahun Anggaran 2007- } \\
2008\end{array}$ & $\begin{array}{l}\text { 1. Tingkat kemandirian keuangan daerah } \\
\text { Kawasan Sarbagita relatif meningkat. } \\
\text { 2. Tingkat efektivitas keuangan Kawasan } \\
\text { Metropolitan Sarbagita semuanya di atas } 100 \\
\text { persen (sangat efektif). } \\
\text { 3. Rata-rata tingkat efisiensi Kawasan } \\
\text { Metropolitan Sarbagita kurang efisien, bahkan } \\
\text { ada yang tidak efisien. } \\
\text { 4. Tingkat keserasian belanja daerah Kawasan } \\
\text { Metropolitan Sarbagita cukup baik dengan } \\
\text { rata-rata } 40 \text { persen. }\end{array}$ \\
\hline 2 & $\begin{array}{l}\text { Djanegara } \\
\& \\
\text { Wakhyudi, } \\
2007\end{array}$ & $\begin{array}{l}\text { Analisis Keterkaitan } \\
\text { Rasio Keuangan Daerah } \\
\text { Dalam Pengukuran } \\
\text { Kinerja Pemda (Studi } \\
\text { pada Setda Kab. Bogor) }\end{array}$ & $\begin{array}{l}\text { 1. Rasio Kemandirian Kabupaten Bogor } \\
\text { cendrung rendah. } \\
\text { 2. Rasio Efektivitas dan efisiensi Kabupaten } \\
\text { Bogor cendrung bagus dan stabil } \\
\text { 3. Rasio aktivitas Kabupaten Bogor masih } \\
\text { mengutamakan belanja rutin. } \\
\text { 4. Rasio pertumbuhan Kabupaten Bogor masih } \\
\text { rendah }\end{array}$ \\
\hline 3 & $\begin{array}{l}\text { Hutajulu, } \\
\text { dkk, } 2012\end{array}$ & $\begin{array}{l}\text { Kajian Pengelolaan } \\
\text { Keuangan Daerah Kab. } \\
\text { Jayapura Pada Era } \\
\text { Otonomi Khusus }\end{array}$ & $\begin{array}{l}\text { 1. Efektivitas pengelolaan keuangan Pemkab } \\
\text { Jayapura kurang efektif } \\
\text { 2. Rasio Pertumbuhan Pemkab Jayapura } \\
\text { cendrung mengalami peningkatan } \\
\text { 3. Trend perkembangan PAD Pemkab Jayapura } \\
\text { meningkat }\end{array}$ \\
\hline 4 & $\begin{array}{l}\text { Unjaswati, } \\
\text { dkk, } 2009\end{array}$ & $\begin{array}{l}\text { Pengukuran Kinerja } \\
\text { APBD Pemkab. Muaro } \\
\text { Jambi }\end{array}$ & $\begin{array}{l}\text { 1. Rasio Kemandirian Pemkab Muaro Jambi } \\
\text { masih rendah } \\
\text { 2. Rasio Efektivitas Pemkab Muaro Jambi cukup } \\
\text { baik }\end{array}$ \\
\hline
\end{tabular}




\begin{tabular}{|l|l|l|ll|}
\hline & & & $\begin{array}{l}\text { Rasio Efisiensi Pemkab Muaro Jambi } \\
\text { cendrung menurun }\end{array}$ \\
\hline 5 & $\begin{array}{l}\text { Susilo \& } \\
\text { Hariadi, } \\
2007\end{array}$ & $\begin{array}{l}\text { Analisis Kinerja } \\
\text { Keuangan Daerah } \\
\text { Sebelum dan Sesudah } \\
\text { Otonomi (Studi Pada } \\
\text { Pemda Propinsi Jawa } \\
\text { Tengah) }\end{array}$ & $\begin{array}{l}\text { 2. } \\
\text { 2ata-rata Rasio Kemandirian Pemda Propinsi } \\
\text { Jawa Tengah setelah OTDA lebih kecil } \\
\text { dibandingkan sebelum OTDA }\end{array}$ \\
& & $\begin{array}{l}\text { Rasio Aktivitas Pemda Propinsi Jawa Tengah } \\
\text { setelah OTDA lebih kecil dibandingkan } \\
\text { sebelum OTDA }\end{array}$ \\
\hline
\end{tabular}

Sumber: Data Diolah, 2013

\subsection{Kerangka Pikir}

Kerangka pikir tentang perbandingan kinerja keuangan Pemerintah Kota Bandar Lampung yang sebelum dan setelah memperoleh opini WTP seperti yang tampak pada gambar berikut ini:

\section{Gambar 1}

Kerangka pikir tentang perbandingan kinerja keuangan Pemerintah Kota Bandar Lampung

\begin{tabular}{|c|c|}
\hline $\begin{array}{c}\text { Kinerja Keuangan Pemerintah } \\
\text { Daerah Kota Bandar Lampung } \\
\text { sebelum Opini WTP }\end{array}$ & $\begin{array}{c}\text { Kinerja Keuangan Pemerintah } \\
\text { Daerah Kota Bandar Lampung } \\
\text { setelah Opini WTP }\end{array}$ \\
\hline $\begin{array}{l}\text { - Rasio Kemandirian Keuangan } \\
\text { Daerah } \\
\text { - Rasio Efektifitas Keuangan } \\
\text { Daerah } \\
\text { - Rasio Efisiensi Keuangan } \\
\text { Daerah } \\
\text { - Rasio Pertumbuhan Keuangan } \\
\text { Daerah } \\
\text { - Rasio Aktivitas Keuangan } \\
\text { Daerah } \\
\text { (Halim, 2004) }\end{array}$ & $\begin{array}{l}\text { - Rasio Kemandirian Keuangan } \\
\text { Daerah } \\
\text { - Rasio Efektifitas Keuangan } \\
\text { Daerah } \\
\text { - Rasio Efisiensi Keuangan } \\
\text { Daerah } \\
\text { - Rasio Pertumbuhan Keuangan } \\
\text { Daerah } \\
\text { - Rasio Aktivitas Keuangan } \\
\text { Daerah } \\
\text { (Halim, 2004) }\end{array}$ \\
\hline
\end{tabular}




\section{Metode Penelitian}

\subsection{Jenis Penelitian}

Jenis penelitian yang digunakan dalam penelitian ini adalah pengujian hipotesis (hypothesis testing), yang bertujuan menguji hipotesis yang dikembangkan berdasarkan teoriteori yang ada dan diuji berdasarkan data yang terkumpul (Sekaran, 2006).

\subsection{Jenis dan Sumber Data}

Jenis data yang digunakan adalah data kuantitatif. Data kuantitatif adalah data dalam bentuk angka-angka dan dapat dinyatakan dalam satuan hitung (Sugiyono, 2007:14). Data kuantitatif yang digunakan dalam penelitian ini adalah Laporan Keuangan Pemerintah Daerah (LKPD) Kota Bandar Lampung tahun 2008 - 2012 yang telah diaudit oleh BPK-RI. Data penelitian ini bersumber dari data sekunder berupa Laporan Hasil Pemeriksaan (LHP) semester II tahun 2012 atas Laporan Keuangan Pemerintah Daerah (LKPD) Kota Bandar Lampung yang diperoleh dari BPK-RI wilayah Bandar Lampung.

\subsection{Metode Pengumpulan Data}

Pengumpulan data dalam penelitian ini dengan metode dokumentasi. Metode dokumentasi dilakukan dengan mengumpulkan data-data yang berasal dari dokumen yang sudah ada. Data yang dikumpulkan berupa Laporan Hasil Pemeriksaan (LHP) semester II tahun 2012 atas Laporan Keuangan Pemerintah Daerah (LKPD) Kota Bandar Lampung tahun $2008-2012$.

\subsection{Variabel Penelitian}

Variabel pada penelitian ini adalah kinerja keuangan dengan indikator pengukuran melalui: rasio kemandirian keuangan daerah, rasio efektivitas keuangan daerah, rasio efisiensi keuangan daerah, rasio pertumbuhan keuangan daerah, rasio aktivitas keuangan daerah.

\subsection{Definisi Operasional Variabel}

Kinerja keuangan pemerintah daerah adalah kemampuan suatu daerah untuk menggali dan mengelola sumber-sumber keuangan asli daerah dalam memenuhi kebutuhannya guna mendukung berjalannya sistem pemerintahan, pelayanan kepada masyarakat dan pembangunan daerahnya dengan tidak tergantung sepenuhnya kepada pemerintah pusat dan mempunyai keleluasaan didalam menggunakan dana-dana untuk kepentingan masyarakat 
daerah dalam batas-batas yang ditentukan peraturan perundang-undangan (Susantih, 2009). Untuk mengukur kinerja keuangan pemerintah daerah digunakan rasio keuangan sebagai berikut:

\section{Rasio Kemandirian Keuangan Daerah}

Kemandirian keuangan daerah yang dimaksud dalam penelitian ini adalah kemampuan suatu daerah untuk membiayai sendiri kegiatan pemerintahan, pembangunan dan pelayanan kepada masyarakat daerahnya. Rumusan rasio kemandirian daerah (Halim, 2002) yaitu :

PAD

Total Pendapatan Daerah

\section{Rasio Efektivitas Keuangan Daerah}

Menggambarkan kemampuan pemerintah daerah dalam merealisasikan PAD yang direncanakan dibandingkan dengan target PAD yang ditetapkan. Rumusan Rasio Efektivitas Keuangan Daerah (Halim, 2002) yaitu :

Realisasi PAD

Target Penerimaan PAD

$$
\mathrm{x} 100 \%
$$

\section{Rasio Efisiensi Keuangan Daerah}

Menggambarkan perbandingan antara realisasi pengeluaran (belanja daerah) dengan realisasi pendapatan daerah. Rumusan Rasio Efesiensi Keuangan Daerah (Halim, 2002) yaitu:

Realisasi Belanja Daerah

Realisasi Pendapatan Daerah

\section{Pertumbuhan Keuangan Daerah (Halim, 2002)}

Rasio pertumbuhan digunakan untuk mengukur seberapa besar kemampuan pemerintah daerah dalam mempertahankan dan meningkatkan keberhasilannya yang telah dicapai dari periode ke periode berikutnya, yang dapat dihitung dengan formula sebagai berikut (Halim, 2002:272).

Pn - Po
Po


Keterangan :

$r \quad=$ Pertumbuhan (dalam persen)

$P n=$ Realisasi pendapatan dan belanja pada tahun $\mathrm{ke}-\mathrm{n}$

$P o=$ Realisasi pendapatan dan belanja pada tahun awal sebelumnya

\section{Aktivitas Keuangan Daerah (Halim, 2004)}

Bagaimana pemerintah daerah memperoleh dan membelanjakan pendapatan daerahnya. Analisis Aktifitas (Rasio Keserasian Belanja) rasio ini menggambarkan bagaimana pemda memprioritaskan alokasi dananya pada belanja modal secara optimal.

\footnotetext{
Belanja modal

Total belanja daerah
}

\subsection{Teknik Analisis}

Metode analisis yang digunakan pada penelitian ini adalah metode kualitatif analisis deskriptif dan kuantitatif Paired Sample t Test.

\section{Hasil dan Pembahasan}

\subsection{Gambaran Umum Objek Penelitian}

Kota Bandar Lampung merupakan sebuah kota dan sekaligus sebagai Ibu Kota Provinsi Lampung. Secara geografis, Provinsi Lampung menjadi pintu gerbang utama pulau Sumatera dan memiliki andil penting dalam jalur transportasi darat dan aktivitas pendistribusian logistik dari Jawa menuju Sumatera maupun sebaliknya. Saat ini Kota Bandar Lampung merupakan pusat pendidikan dan kebudayaan serta perekonomian di Provinsi Lampung.

Sejak berdirinya Kota Bandar Lampung upaya peningkatan potensi-potensi yang ada terus dilakukan dengan upaya peningkatan pembangunan daerah yang dilakukan melalui perencanaan, pelaksanaan dan pengawasan pembangunan yang lebih terpadu dan terarah agar sumber daya yang ada dapat dimanfaatkan secara efektif dan efisien. Perkembangan pembangunan yang digerakkan pemerintah, swasta dan masyarakat sebagian dilakukan dalam rangka deregulasi dan debirokratisasi sebagai terobosan terhadap tatanan yang ada untuk mempercepat terapainya pertumbuhan dan pemerataan pembangunan serta persiapan menghadapi era globalisasi. 


\subsection{Analisis Deskriptif}

Penelitian ini bertujuan untuk mengetahui perbandingan kinerja keuangan Pemerintah Kota Bandar Lampung Tahun Anggaran 2008 - 2012. Untuk mengukur kinerja keuangan Pemerintah Kota Bandar Lampung dalam mengelola keuangan daerahnya dilakukan dengan menggunakan rasio kemandirian keuangan daerah, rasio efektifitas keuangan daerah, rasio efisiensi keuangan daerah, rasio pertumbuhan keuangan daerah dan rasio akitivitas keuangan daerah. Berdasarkan hasil pengolahan data, maka Kinerja Keuangan Pemerintah Kota Bandar Lampung Tahun Anggaran 2008 yang memperoleh Opini Tidak Memberikan Pendapat, 2009 memperoleh Opini WDP dan 2010 hingga 2012 memperoleh opini WTP adalah sebagai berikut:

Tabel 2

Kinerja Keuangan Pemerintah Kota Bandar Lampung tahun 2008-2012

\begin{tabular}{|c|c|c|c|c|c|}
\hline Tahun & $\begin{array}{c}\text { Rasio } \\
\text { Kemandirian }\end{array}$ & $\begin{array}{c}\text { Rasio } \\
\text { Efektivitas }\end{array}$ & $\begin{array}{c}\text { Rasio } \\
\text { Efisiensi }\end{array}$ & $\begin{array}{c}\text { Rasio } \\
\text { Pertumbuhan }\end{array}$ & $\begin{array}{c}\text { Rasio } \\
\text { Aktivitas }\end{array}$ \\
\hline 2008 & $9,05 \%$ & $111,98 \%$ & $104,12 \%$ & $15,14 \%$ & $16,04 \%$ \\
\hline 2009 & $8,87 \%$ & $97,81 \%$ & $101,08 \%$ & $4,51 \%$ & $10,26 \%$ \\
\hline 2010 & $9,04 \%$ & $102.99 \%$ & $96,66 \%$ & $18,21 \%$ & $10,31 \%$ \\
\hline 2011 & $13,71 \%$ & $103,84 \%$ & $97,06 \%$ & $24,11 \%$ & $9,53 \%$ \\
\hline 2012 & $20,47 \%$ & $102,19 \%$ & $100,32 \%$ & $24,89 \%$ & $20,05 \%$ \\
\hline Jumlah & $61,14 \%$ & $518,81 \%$ & $499,24 \%$ & $86,86 \%$ & $66,19 \%$ \\
\hline Rata-Rata & $12,23 \%$ & $103,76 \%$ & $99,85 \%$ & $17,37 \%$ & $13,24 \%$ \\
\hline Minimum & $8,87 \%$ & $97,81 \%$ & $96,66 \%$ & $4,51 \%$ & $9,53 \%$ \\
\hline Maximum & $20,47 \%$ & $111,98 \%$ & $104,12 \%$ & $24,89 \%$ & $20,05 \%$ \\
\hline
\end{tabular}

Sumber: Data Diolah, 2014

\subsection{Analisis Kuantitatif}

Dari hasil pengujian seluruh rasio kinerja keuangan Pemerintah Daerah Kota Bandar Lampung sebelum dan setelah memperoleh opini WTP menggunakan Paired Sampel t Test, maka diperolehlah hasil sebagai berikut :

Tabel 3

Paired Samples Statistics

\begin{tabular}{|ll|l|l|l|l|}
\hline & & & $\begin{array}{l}\text { Std. } \\
\text { Deviation }\end{array}$ & $\begin{array}{l}\text { Std. Error } \\
\text { Mean }\end{array}$ \\
\hline Pair 1 & Mean & $\mathrm{N}$ &. &. \\
& Sebelum WTP & 38.7800 & $1^{\mathrm{a}}$ &. &. \\
\hline
\end{tabular}

Sumber: Data Diolah, 2014 
Berdasarkan hasil pengujian tersebut maka dapat dibuat kesimpulan terdapat perbedaan rata-rata kinerja keuangan Pemerintah Daerah Kota Bandar Lampung setelah memperoleh opini WTP. Hal ini dapat dilihat dari nilai mean setelah opini WTP $(50.2200)>$ dari nilai mean sebelum opini WTP (38.7800) (Priyatno, 2008).

\section{Kesimpulan dan Saran}

\subsection{Kesimpulan}

Berdasarkan hasil analisis kinerja keuangan Pemerintah Daerah Kota Bandar Lampung tahun anggaran 2008 - 2012, maka dapat disimpulkan sebagai berikut: Kinerja Keuangan Pemerintah Daerah Kota Bandar Lampung setelah Opini WTP berbeda dengan sebelum Opini WTP yang artinya Kinerja Keuangan Pemerintah Daerah Kota Bandar Lampung setelah Opini WTP lebih baik sebelum Opini WTP.

\subsection{Saran}

Berdasarkan kesimpulan diatas penulis menyarankan hal-hal sebagai berikut:

1. Untuk meningkatkan Kemandirian Keuangan Daerah maka Pemerintah Daerah Kota Bandar Lampung diminta untuk menggali potensi - potensi pendapatan daerah yang belum tersentuh dan melakukan pengawasan yang efektif terhadap pemungutan pajak dan retribusi.

2. Untuk meningkatkan Efisiensi Keuangan Daerah maka Pemerintah Daerah Kota Bandar Lampung disarankan untuk melakukan pembelanjaan daerah sesuai dengan kebutuhan daerah dan melakukan pengawasan ketat terhadap pembelajaan daerah.

\subsection{Keterbatasan Penelitian}

Penelitian ini memiliki keterbatasan sebagai berikut:

1. Indikator pengukuran kinerja keuangan yang digunakan pada penelitian ini terbatas pada rasio kemandirian, rasio efektifitas, rasio efisiensi, rasio pertumbuhan dan rasio aktivitas. Penelitian selanjutnya diharapkan dapat memperluas indikator pengukuran dengan menambahkan pengukuran-pengukuran lainnya, sehingga hasil penelitian akan lebih baik lagi.

2. Hanya terbatas pada Pemerintah Kota Bandar Lampung. Penelitian selanjutnya diharapkan dapat melakukan penelitian kepada seluruh provinsi Lampung. 


\section{Daftar Pustaka}

Bastian, Indra. 2001. Analisis Kinerja Keuangan Daerah Indonesia. Jurnal Akuntansi Sektor Publik di Indonesia. Yogyakarta.

Devas, et.al. 1989. Analisis Pendapatan Asli Daerah dan Kinerja Keuangan. Jurnal Otonomi Daerah. Bali.

Djanegara dan Wakhyudi. 2007. Analisis Keterkaitan Rasio Keuangan Daerah Dalam Pengukuran Kinerja Pemda. Bogor.

Erawati, Ni Made Adi. 2009. Analisis Kinerja Keuangan Kawasan SARBAGITA Tahun Anggaran 2007-2008. Denpasar.

Evana. 2012. Pengelolaan Keuangan Negara yang baik oleh BPK RI. Jurnal Media Indonesia tentang Info Daerah. Bandar Lampung.

Halim, Abdul. 2001. Definisi Keuangan Daerah : "Akuntansi Keuangan Daerah, Edisi 3". Jakarta Salemba Empat.

Halim, Abdul. 2002. Rumusan Rasio Keuangan Daerah : "Akuntansi Keuangan Daerah, Edisi 3". Jakarta Salemba Empat.

Halim, Abdul. 2004. Rasio Keuangan Pemerintah Daerah : "Akuntansi Keuangan Daerah, Edisi 3”. Jakarta Salemba Empat.

Halim, Abdul. 2007. Akuntansi Sektor Publik : "Akuntansi Keuangan Daerah, Edisi 3". Jakarta Salemba Empat.

Hutajulu, Halomoan. 2012. Analisis Kajian Pengelolaan Keuangan Daerah Kabupaten Jayapura Pada Era Otonomi Khusus. Yogyakarta.

Kawedar, Warsito. 2008. Pendekatan Penganggaran Daerah dan Akuntansi Keuangan Daerah. Jurnal Akuntansi Sektor Publik. Semarang.

Mahmudi. 2007. Analisis Laporan Keuangan Pemerintah Daerah. Yogyakarta : UPP STIM YKPN.

Mardiasmo. 2002. Tujuan Kinerja Keuangan Pemerintah Daerah. Jurnal Analisis Kinerja Keuangan.

Mardiasmo. 2005. Anggaran Pendapatan dan Belanja Daerah. Jurnal Analisis Kinerja Keuangan APBD.

Priyatno, Dwi. 2008. Analisis Data dengan Perangkat Lunak SPSS. Jurnal Mandiri Belajar SPSS. Yogyakarta : Mediakom.

Purnomo, Hadi. 2012. Opini WTP Bukan Berarti Tidak Ada Korupsi. Jurnal Inverstor Daily BPK Opini WTP. Jakarta. 
Rai, I Gusti Agung. 2008. Definisi Audit Sektor Publik. Jurnal Konsep, Praktik, dan Studi Kasus Manajer Penerbitan dan Produksi : Edward Tanujaya. Jakarta.

Sekaran, Uma. 2006. Metodologi Penelitian untuk Bisnis, Edisi 4. Jakarta Salemba Empat.

Soepardi, Eddy Mulyadi. 2013. Pemerintah Daerah Jangan Bangga dengan Opini WTP. Jurnal Media Tribun. Bandar Lampung.

Sucipto. 2005. Analisis Pencapaian Kinerja Keuangan. Jurnal Akuntansi Kinerja Keuangan Pemerintah Daerah. Universitas Sumatera.

Sugiyono. 2004. Analisis Deskriptif dalam Metode Penelitian Kualitatif. Penerbit Alfabeta. Jakarta.

Sugiyono. 2007. Metode Penelitian Kuantitatif dan Kualitatif. Penerbit Alfabeta. Jakarta.

Susantih. 2009. Analisis Pengaruh Pendapatan Asli Daerah. Jurnal Analisis Perbandingan Kinerja Keuangan Pemerintah Daerah. Palembang.

Susilo, Gideon Tri Budi dan Hariadi, Priyo. 2007. Analisis Kinerja Keuangan Daerah Sebelum dan Sesudah Otonomi. Jawa Tengah.

Syamsi. 1986. Evaluasi Kinerja Keuangan dan Tingkat Kesejahteraan Masyarakat. Yogyakarta.

Unjaswati, Shinta. 2009. Analisis Kinerja APBD dalam Pemerintah. Jurnal Pengukuran Kinerja APBD Pemerintah Kabupaten Muaro. Jambi.

Permendagri: Peraturan Pemerintah No. 24 Tahun 2005

Permendagri: Peraturan Pemerintah No. 21 Tahun 2011 